Table 1. DISTRIBLTION OF RADIOACTIVITY OF THYMINES AND THYMINE DIMERS IN TCA-SOLUBLE FRACTIONS FROM EHRLICH ASCITES TUMOUR CELL

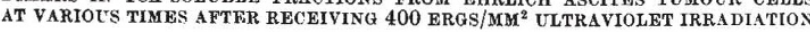

\begin{tabular}{ccc} 
& \multicolumn{2}{c}{ C.p.m. above background* } \\
Time $(\mathrm{h})$ & Thymine & Thymine dimer \\
0 & 243 & 3 \\
24 & 157 & 57 \\
48 & 96 & 69 \\
120 & 49 & 51
\end{tabular}

* Ten minute counts: background was about 25 c.p.m.

In other experiments wo found that caffeine can block the dark reactivation process in Ehrlich ascites tumour cells irradiated with ultraviolet light, but it does not reduce the ability of cells irradiated with ionizing radiation to form colonies. The differences in the sensitivity of the three cell lines to X-rays and ultraviolet light and the difference in the effects of caffeine on $X$ - and ultraviolet-irradiated Ehrlich cells probably indicate that the dark reactivation processes which act on damage induced by ultraviolet radiation do not act on damage induced by ionizing radiation.

We thank Professor Allen S. Fox for advice and sug. gestions.

Masakatsu Horikawa

OSamu Nikaido

Tsutomu Sugahara

Department of Experimental Radiology,

Faculty of Medicine,

University of Kyoto,

Kyoto,

Japan.

Received January 22; revised March 25, 1968.

${ }^{1}$ Wulff, D. L., and Rupert, C. S., Biochem. Biophys. Res. Commun., 7, 237 (1962).

${ }^{2}$ Setlow, R. 13., and Carrier, W. L., Proc. US Nat. Acad. Sci., 51, 226 (1964).

${ }^{3}$ Boyce, R. P., and Howard-Flanders, P., Proc. US Nat. Acad. Sci., 51, 293

4 Rauth, A. M., Radiat. Res., 31, 121 (1967).

${ }^{5}$ Trosko, J. F., Chu, E. H. Y., and Carrier, W. L., Radiat. Res., 24, 667 (1965),

${ }^{6}$ Regan, J. D., and Trosko, J. E., Radiat. Res., 31, 548 (1967).

\section{Cannibalism and Predation by Aphids}

APHIDs are usually regarded as feeding exclusively on plant sap which they ingest through stylet-like mouth parts, but they have occasionally been seen to feed on animal food. During feeding on a turgid plant, they do not have to suck but depend chiefly on the pressure of the sap for ingestion. They can, however, suck through artificial membranes on food that is under negligible pressure. This communication collates records of cannibalism and predation among aphids.

Girault $^{1}$, in Ohio, observed a winged female and six larvae of an unspecified plum aphid feeding on eggs of the predaceous coccinellid, Megilla maculata De Geer, in captivity. Each aphid inserted its stylets and completely absorbed the contents of a single egg which gradually collapsed. Kurisaki ${ }^{2}$ recorded several species of citrus aphid in Japan feeding in the field on eggs of the aphid predator, Chrysopa cognata Okamoto. About 30 per cent were sucked out by aphids during August. Two unspecified species of aphid also destroyed about 3 per cent of eggs

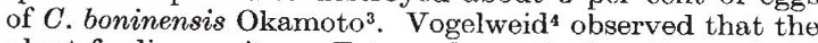
plant-feeding mites, Tetranychus telarius L. and $T$. althaeae Hanst., did not occur on hop plants, Humulus lupulus, in the lower Rhineland when aphids (unspecified) were present; aphids were seen to attack the mites and absorb their body fluids. Takahashi ${ }^{5}$ reported that wingless adults and larvae of the aphid, Astegopteryx styracicola Takah., feed on the tree, Styrax suberifolium, in some parts of Formosa, emerge from their galls and crawl along branches from which they fall if they are shaken or disturbed. The aphids cause intense irritation of human skin because Takahashi says the aphids' stylets penetrate the skin. The aphids, however, may produce some irritant on their body surfaces.

Pintera $^{6}$ recorded starving Myzus persicae Sulz. attacking other dying aphids in dishes and noticed sucking movements by the cannibals. While experimenting with cultures of Megoura viciae Buckt., one of us (J. H.) often saw cannibalism. The aphids were reared on caged isolated broad bean plants (Vicia faba) growing in tap water until the seeds rotted; the temperature was always $25^{\circ} \pm 1^{\circ} \mathrm{C}$ and the relative humidity in the cages was usually about 50 per cent.

Cannibalism occurred regularly when the endosperm of the seeds had been consumed, the plants were not growing and the leaves at the tops dying. The aphids then left even lightly infested plants, so overcrowding was apparently not a cause of cannibalism. Aphids that had left the plants often tried again to feed on them and it was then that they often attacked aphids still feeding on the plants.

Attacks were most often made by first and second instar larvae on the fourth instar larvae and adults; two or three young larvae commonly attacked one adult apterous female. The site of attack seemed to be haphazard. Larvae that had attacked other aphids sometimes produced small drops of honeydew when put in small eages without plants, which suggests that they had fed on their hosts.

When transferred to fresh plants, attacked aphids usually fed and reproduced normally, but some could not co-ordinate their legs. Larvae that had attacked other aphids usually failed to feed on fresh plants and died.

Cannibalism was not seen among colonies of Aphis fabae Scop. and $A$. craccivora Koch kept on $V$. faba in the same conditions.

Two of us (C. J. B. and E. D. M. M.) have also seen cannibalism in a small group of $M$. viciae in a plastic box cage enclosing a leaf of $V$. faba. The air was dry, the leaf was dying and most of the aphids were crawling about in the box. Only one aphid was feeding on the green remains of the leaf and it was being attacked by another aphid. We also once saw cannibalism among Acyrthosiphon pisum Kalt. confined in dishes without plant tissue.

Cannibalism therefore seerns to occur among these aphids when the plants deteriorate and the aphids are starving. The method of feeding on the prey is uncertain but presumably the attacker feeds on the fluids in the host's gut or in its body cavity which are under some pressure and possibly acquired without the need to suck. Chrysopid and coccinellid eggs are presumably under much less internal pressure and prodatory aphids probably have to suck at the contents. It is interesting that all three species in which cannibalism has been recorded are green; $A$. fabae and $A$. craccivora are black.

We thank Dr V. Eastop for his help with references, Dr K. Nakasono for translating from Japanese and Dr A. Pintera for details of his observations.

\section{J. BANKS \\ E. D. M. Macaulay}

Rothamsted Experimental Station,

Harpenden, Hertfordshire.

\section{J. Holman}

Entomological Institute,

Acadomy of Sciences,

Prague,

Czechoslovakia.

Received April 3, 1968.

${ }^{1}$ Girault, A. A., Entomol. News, 19, 132 (1908).

${ }^{2}$ Kurisaki, M., Insect World, Giru, 24, 115 (1920).

- Kurisaki, M., Insect World, Giru, 24, 189 (1920).

4 Vogelweid, V., Bull. Assoc. Philomatique d'Alsace et de Lorraine, Saverne, 6 (1921), 71 (1922).

s 'Takahashi, R., Trans. Nat. Hist. Soc. Formosa, 20, 43 (1930).

'Pintera, A., Rozpravy, CSA V, 67, 1-46 (1957). 